\title{
ANALISA KUALITAS SISTEM INFORMASI E-RAPORT PADA SEKOLAH SMPN 5 KOTA TANGERANG TERHADAP KEPUASAN PENGGUNA MENGGUNAKAN METODE WEBQUAL 4.0.
}

\author{
Monalisa Monalisa ${ }^{1}$, Imron Imron ${ }^{2}$, Albert Riyandi ${ }^{3}$ \\ ${ }^{1,3}$ Sistem Informasi \\ Sekolah Tinggi Manajemen Informatika dan Komputer Nusa Mandiri \\ www.nusamandiri.ac.id \\ E-mail:11196095@nusamandiri.ac.id ${ }^{1}$, albert.abe@nusamandiri.ac.id ${ }^{3}$ \\ ${ }^{2}$ Sistem Informasi \\ Universitas Bina Sarana Informatika \\ www.bsi.ac.id \\ E-mail:imron.imr@bsi.ac.id ${ }^{2}$
}

\begin{abstract}
ABSTRAK
Sistem e-Raport digunakan sebagai sistem informasi yang dirancang oleh sekolah untuk melakukan penginformasian terhadap perkembangan siswa kepada orang tua, yang telah dilaksanakan hampir diseluruh sekolah Negeri di Indonesia. SMPN 5 Kota Tangerang adalah salah satu sekolah negeri di Kota Tangerang yang menggunakan Sistem e-Raport sebagai media pengganti laporan hasil belajar siswa secara manual. Permasalahan yang diangkat adalah apakah kualitas dari Sistem e-Raport berpengaruh terhadap kepuasan pengguna. Penelitian ini berfokus pada kepuasan pengguna Sistem e-Raport menggunakan metode webQual 4.0 yang terdiri dari 3 variabel yaitu kualitas kegunaan (usability), kualitas informasi (information quality), dan kualitas interaksi (interaction quality). Data yang digunakan adalah data primer, yaitu dengan menyebar kuesioner menggunakan skala likert dengan 20 butir pernyataan kepada 400 responden. Data yang terkumpul setelahnya diolah menggunakan analisis regresi linier berganda menggunakan software SPSS. Berdasarkan variabel webQual 4.0, hasil analisis menunjukan kualitas kegunaan, kualitas Informasi, dan kualitas interaksi berpengaruh terhadap kepuasan pengguna.
\end{abstract}

Kata Kunci : Sistem e-Raport, WebQual 4.0, SPSS, Kualitas Sistem, Sikap Kepuasan Pengguna, Raport

\section{PENDAHULUAN}

\subsection{Latar Belakang}

Internet adalah salah satu bagian yang paling penting dan berharga pada bidang pendidikan karena memberikan begitu banyak informasi, diantaranya sebagai sumber referensi paling besar bagi para pendidik dan siswa yang ingin belajar dan mengasah kemampuannya. Pada pelaksanaannya, penggunaan internet di bidang pendidikan khususnya pada jenjang pendidikan sekolah menengah biasanya meliputi e-Learning, e-Raport dan dan lain sebagainya. Salah satu contoh penerapan yang ada di sekolah; website sekolah. Brrtujuan untuk menunjang berbagai dimensi di bidang pendidikan.

Apa itu website sekolah? website sekolah dapat diartikan sebagai sebuah website yang berisi tentang fitur-fitur pendidikan bertujuan memberikan informasi dan pelayanan tentang sebuah sekolah kepada para pengguna. Pada SMPN 5 Kota Tangerang pemanfaatan website sekolah sendiri adalah terbangunnya sistem $e$-Raport pada salah satu menu di website sekolah.

Raport adalah bentuk aktivitas penilaian yang dilaksanakan guna mengukur, menilai, dan mengevaluasi tingkat dan kualitas pencapaian Kompetensi Dasar. Penilaian digunakan untuk mengetahui kekuatan serta kelemahan dalam proses pembelajaran siswa sehingga bisa dijadikan dasar dan patokan guna mengambil keputusan serta perbaikan proses pembelajaran yang telah dilakukan untuk kedepannya nanti, maka demikian dibuatlah sistem penilaian berbasis $e$-Raport.

Seperti yang diketahui bersama, selama ini proses penilaian yang beroperasi masih menggunakan teknik manual yang belum terkomputerisasi; dimana guru dan wali kelas menuliskan laporan hasil belajar tersebut dengan menulis menggunakan kertas dan pulpen. Setelah diluncurkan e-Raport maka penilaian Raport bisa dilakukan dengan digital yang mana guru merencanakan penilaian lalu mengekskusi proses penilaian tersebut dalam bentuk laporan secara semi online. e-Raport membuat para guru termotivasi untuk memanfaatkan kemajuan teknologi tersebut, data-data nilai yang sudah didapat bisa langsung diolah dalam sistem yang sudah ada. Setelah memasukkan data ke dalam server pengguna informasi selanjutnya, yaitu para siswa dan wali murid yang ingin mengetahui hasil belajarnya yang ditempuh selama satu semester bisa mengaksesnya di website sekolah.

Dalam penerapan sistem e-Raport di website sekolah SMPN 5 Kota Tangerang ditemukan 
beberapa permasalahan ketika menggunakan sistem $e$-Raport sehingga menyebabkan pengguna informasi masih kurang puas terhadap kualitas sistem e-Raport tersebut karena sistem yang sering mengalami maintenance atau kendala lain seperti jaringan yang gagal terhubung, lambat, kesulitan masuk pada server, tampilan yang masih kurang menarik, keterlambatan informasi, beberapa kesalahan teknis, ataupun human error.

Kepuasan bagi pengguna akan tumbuh ketika kualitas sistem informasi yang sesuai dengan kebutuhan dan keperluan penggunanya itu sendiri. Karenanya diperlukan pengukuran kepuasan pengguna terhadap sistem e-Raport untuk meningkatkan performalitas demi menjaga keberlangsungan proses pada sistem $e$-Raport yang akan terus mengalami perkembangan yang berkesinambungan atau perbaikan di kemudian hari.

Kualitas website terdiri dari tiga kriteria penilaian diantaranya; usability (kegunaan), information quality (kualitas informasi), dan service interaction quality (kualitas interaksi layanan) tiga komponen yang disebutkan terdapat dalam parameter komponen yang hadir pada metode WebQual.

Guna mengidentifikasi secara lebih lanjut variabel-variabel yang sudah ada dan pembuktian apakah sistem informasi e-Raport mampu memenuhi keinginan para pengguna, maka perlu digunakan metode analisis WebQual untuk mengidentifikasi berbagai bentuk kepuasan ataupun bagian-bagian penting yang harus ditunjukkan dan ditingkatkan oleh sistem e-Raport ini, sehingga diharapkan dapat memenuhi kepuasan para pengguna informasi yang dilihat dari persepsi ataupun harapan pengguna terhadap sistem $e$ Raport..

\subsection{Tinjuan Pustaka}

\section{a. Sistem Informasi}

Sistem informasi adalah sistem di dalam organisasi yang mempertemukan kebutuhan pengelolaan transaksi harian secara terus-menerus, mendukung operasi yang sedang berjalan, bersifat manajerial dan kebutuhannya dengan kegiatan strategi dari suatu organisasi yang menyediakan pihak luar tertentu menggunakan laporan-laporan yang diperlukan (Wildaningsih and Yulianeu 2018). Dan dapat ditarik kesimpulan definisi sistem informasi merupakan suatu kegiatan ataupun aktivitas yang melibatkan beberapa proses yang berisi informasi untuk digunakan sebagai pencapaian tujuan.

\section{b. E-Raport}

e-Raport adalah perangkat lunak atau aplikasi berbasis web yang mempunyai fungsi untuk memanajemen penilaian dan penyusunan laporan capaian kompetensi hasil peserta didik atau raport pada satuan pendidikan (kemendikbud 2017). $e$ Raport SMP adalah aplikasi berbasis web, di mana dalam satu sekolah aplikasi ini cukup diinstal pada server atau komputer yang difungsikan sebagai server. Sedangkan client (dalam hal ini admin, guru, wali kelas, dan peserta didik,kepala sekolah dan orang tua) dapat mengakses melalui komputer lain yang terhubung melalui jaringan baik internet, maupun intranet, dengan menggunakan web browser.

\section{c. Kepuasan Pengguna}

Suatu pencapaian ekspektasi yang dirasakan pengguna untuk mendapatkan sebuah informasi yang dibutuhkan dalam sistem informasi yang telah diakses oleh si pengguna itu sendiri (Darwi and Efrizon 2019), maksudnya adalah sesuatu yang dibutuhkan diinginkan, diharapkan, dan dirasakan di dalam diri pengguna untuk membandingkan sebuah pelayanan ataupun hasil dari kinerja sebuah sistem informasi dalam pelaksanaan atau pelayanan tertentu.

\section{d. Metode WebQual}

WebQual merupakan pengembangan dari metode sebelumnya yaitu servqual yang sudah banyak digunakan penelitian sebelumnya untuk mengukur kualitas jasa. WebQual berbasis pada quality function deployment atau QFD (Imron 2019a). WebQual juga sering disebut sebagai website quality atau pengukuran kualitas website yaitu adalah instrumen yang dikembangkan guna menilai kegunaan informasi maupun interaksi jasa dari website yang ada di internet

\subsection{Metodologi Penelitian}

Dalam upaya untuk mengumpulkan data dalam penulisan penelitian ini, metode yang digunakan adalah kuantitatif dengan pengumpulan data yang menggunakan teknik survei dengan penyebaran kuesioner kepada responden yang sudah dipilih menjadi sampel. Kuesioner dibuat dengan instrumen berdasarkan pada metode webQual 4.0, yang terdiri dari tiga variabel bebas atau independen yaitu X1 dengan label kualitas kegunaan, X2 dengan label kualitas informasi dan X3 dengan label kualitas interaksi, dan satu lagi variabel terikat atau variabel dependen yaitu variabel Y dengan label kepuasan pengguna.

Responden atau para sampel yang terlibat dalam penelitian ini adalah para guru, para siswa, admin, kepala sekolah, yang menggunakan vasilitas sistem e-Raport. Sampel yang diambil menggunakan teknik simple random sampling untuk memilih bagian dari populasi.

Pengambilan sampel dilakukan dengan cara menyebarkan kuesioner kepada responden dengan cara membagikan link $e$-form kuisioner di grup kelas oleh para wali kelas.

Setelah kuesioner terkumpul hasil kuesioner akan disaring, diklasifikasi lalu ditabulasi. Dari data tersebut diperoleh sebanyak 400 data yang terdiri dari para guru dan siswa siswi yang tersebar 
di 30 kelas di SMPN 5 Tangerang. Data yang yang telah ditabulasi tersebut kemudian dianalisis menggunakan metode webQual dan metode kuantitatif standar yaitu meliputi uji validitas, uji reliabilitas, uji asumsi klasik (yang terbagi lagi menjadi 4 yaitu itu uji normalitas, uji multikolinearitas, uji heteroskedastisitas, dan uji linieritas), koefisiensi determinasi dan korelasi, uji t, dan uji F.

\section{PEMBAHASAN}

Tahap penelitian dilaksanakan peneliti untuk membuat tahapan atau proses penelitian dalam penelitian ini terdapat alur penelitian atau tahap yang seperti berikut;

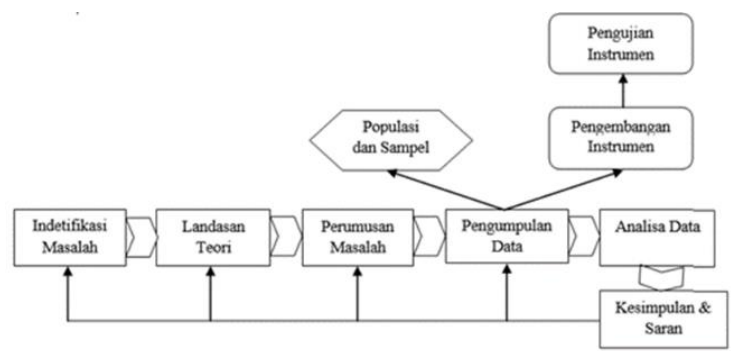

Sumber: (Sugiyono, 2017:30)

Ada pun metode yang digunakan dalam penelitian ini adalah sebagai berikut.

\section{Metode Pengumpulan Data}

Data yang diperoleh terkait analisis kualitas sistem e-Raport terhadap kepuasan pengguna pada SMPN 5 Kota Tangerang yang beralamat di http:/smpn5kotatangerang.sch.id/ mempunyai indikator-indikator yang dijadikan sebagai landasan dalam menyusun item-item yang bisa dijadikan sumber guna memperoleh data-data, yaitu dengan metode pengumpulan data sebagai berikut;

a. Observasi, suatu teknik pengumpulan data dengan cara pengamatan langsung terkait objek yang sedang diteliti. Pengamatan tersebut dilaksanakan untuk mengukur bagaimana kepuasan pengguna sistem e-Raport pada SMPN 5 Kota Tangerang.

b. Studi pustaka, mencari dan mengumpulkan data dan bahan yang berkaitan dengan suatu masalah yang sedang diteliti untuk mendapatkan landasan teori yang cukup kuat guna mempertanggungjawabkan hasil dari analisa data yang telah diperoleh.

c. Wawancara, dalam penelitian ini, data dan informasi didapatkan mengenai kepuasan pengguna dalam menggunakan sistem $e$ Raport melalui sebuah wawancara secara langsung kepada para pengguna sistem tersebut yaitu para dewan guru, siswa-siswi, operator dan kepala sekolah.

d. Dokumentasi, mencari data tentang sejarah berdirinya SMPN 5 Kota Tangerang, visi misi sekolah tersebut, struktur organisasi dan dokumentasi lain yang berkaitan dengan penelitian ini.

e. Angket atau kuesioner diperoleh dengan cara menyebarkan kuesioner yang berbentuk $e$-form dengan menggunakan media onedrive, link-nya disebarkan pada masing-masing grup kelas. Penelitian ini merupakan penelitian yang dilakukan dengan mengumpulkan data kuantitatif dan memberikan pernyataan yang dibuat untuk mengetahui bagaimana instrumen antara kualitas kegunaan, kualitas informasi, kualitas interaksi, dan kepuasan pengguna. kuesioner digunakan untuk mengumpulkan pendapat dari pengguna presensi e-Raport. kuesioner yang diajukan berisi total 20 pertanyaan dengan spesifikasi skor pernyataan untuk masing-masing variabel. Link untuk $e$ form kuisioner guru dan siswa yang dibuat terpisah karena ada beberapa detail yang berbeda untuk guru dan siswa seperti pemilihan Bahasa dan detail mengenai informasi pribadi.

\section{Populasi}

Dalam penelitian ini populasi adalah keseluruhan objek yang menjadi sasaran penelitian yaitu seluruh warga sekolah SMPN 5 Tangerang yang menggunakan atau pernah menggunakan website atau sistem dari e-Raport meliputi para siswa beserta orang tuanya, para guru, operator, dan kepala sekolah. Jumlah populasi terdiri dari 1089 orang yang terbagi dari 45 guru dan 1044 siswa.

\section{Sampel}

Sampel adalah bagian dari populasi yang menjadi karakteristik yang dimiliki oleh populasi itu titik maka dari itu sampel diambil dari populasi si artinya betul-betul mewakili (representative). Teknik sampling atau metode pengambilan sampel yang digunakan pada penelitian ini adalah simple random sampling yang mana teknik pengambilan sampel dari populasi dilakukan secara acak. Demi menentukan jumlah sampel dipilih menggunakan rumus Solvin guna mengukur sampelnya. Berikut rumusnya;

$$
\begin{aligned}
& \mathrm{n}=\frac{N}{1+\mathrm{N}(\mathrm{e}) 2} \\
& \mathrm{n}=\frac{1089}{1+1089(0,05) 2} \\
& \mathrm{n}=\frac{1089}{2,725}=399,63 \\
& \mathrm{n}=400
\end{aligned}
$$

Keterangan:

n: ukuran sampel

$\mathrm{N}$ : populasi

e: tingkat ketepatan (presisi) 5\% $(0,05)$

Secara rinci jumlah populasi dan sampel dalam penelitian ini dapat disajikan berupa tabel seperti berikut ini: 
Tabel I

Populas dan Sampel

Sumber : SMPN 5 Tangerang (2020)

\begin{tabular}{|c|c|c|c|c|}
\hline \multirow{2}{*}{1} & \multirow{2}{*}{ Ket } & $\begin{array}{c}\text { Jenis } \\
\text { Kelamin }\end{array}$ & Populasi & Sampel \\
\hline \multirow{2}{*}{ Guru } & Laki-laki & 30 & 23 \\
\cline { 3 - 5 } 2 & \multirow{2}{*}{ Siswa } & Perempuan & 15 & 8 \\
\cline { 3 - 5 } & & Paki-laki & 538 & 237 \\
\hline \multicolumn{3}{|c|}{ Total } & 506 & 132 \\
\hline
\end{tabular}

4. Metode Analisis Data

a. Tabulasi Data

Kuesioner yang sudah diisi oleh responden melalui OneDrive Form diseleksi kelengkapan pengisiannya dan data yang sudah di seleksi diberi skor sesuai dengan variabel dan klasifikasinya, dan selanjutnya ditabulasi dengan menggunakan perangkat lunak Microsoft Excel.

\section{Uji Asumsi Klasik}

Sebelum melakukan analisis dengan regresi linear berganda, perlu dilakukan uji persyaratan analisis a terlebih dahulu yang sering disebut dengan uji asumsi klasik. Uji asumsi klasik meliputi uji normalitas, uji multikolinieritas, uji heterokedastisitas, uji linearitas, dan uji autokorelasi.

\section{a. Uji Normalitas}

Uji normalitas dilakukan guna memahami apakah data yang didapat berasal dari populasi yang telah terdistribusi secara normal atau berada dalam persebaran yang normal (Kharisma and Anggraeni 2018). Data bisa dikatakan berdistribusi normal hanya jika signifikansinya lebih besar dari 0.05.

\section{b. Uji Multikolinieritas}

Multikolinearitas adalah sebuah keadaan dimana dua atau lebih variabel dependen pada model regresi terdapat hubungan linier yang sempurna atau mendekati sempurna (Imron 2019a). Model regresi yang baik adalah tidak adanya multikolinearitas.

\section{c. Uji Heterokedastisitas}

Heterokedastisitas adalah tidak konstannya suatu varian atau macam varian yang terus berubahubah. Dalam analisa statistik terdapat beberapa cara untuk mengetahui dan mendeteksi keberadaan gejala heteroskedastisitas yaitu salah satunya dengan melihat pada gambar scatterplots.

Pada uji heteroskedastisitas pengambilan keputusan adalah dengan cara melihat pola pada gambar. Syarat yang harus dipenuhi bahwa tidak adanya terjadi gejala heteroskedastisitas apabila;

i. Penyebaran pada titik-titik di atas dan di bawah atau di sekitar angka 0 .

ii. Titik-titik tidak mengumpul hanya di atas atau di bawah saja.

iii. Titik-titik tidak membuat satu pola tertentu.

iv. Titik-titik tidak boleh membuat suatu pola apalagi gambar gelombang melebar

v. kemudian menyempit atau melebar kembali.

d. Uji Linieritas
Menurut Widiyanto Uji linearitas adalah hubungan yang linear antara peubah-peubah dalam suatu model. Cara untuk mengetahui suatu variabel independen dan variabel dependen menujukkan atau memiliki hubungan yang linier atau tidak, maka dapat dilakukan dengan membandingkan nilai signifikansi deviation from linearity. Definition for linearity menunjukkan seberapa jauh sebuah data atau model persamaan regresi linier berganda menyimpang dari model linier nya sendiri.

Apabila deviation from linearity memiliki sig lebih besar dari 0,05 itu tidak menunjukkan signifikansi, maka terdapat sebuah hubungan yang linier. sedangkan, jika nilai deviation from linearity lebih kecil dari 0,05 yang menujukkan signifikansi maka tandanya tidak terdapat hubungan yang linier.

\section{Uji Regresi Linier Berganda}

Regresi linear berganda merupakan salah satu pengembangan dari metode regresi linier sederhana. Tujuan dari regresi linear berganda adalah untuk mengestimasi nilai variabel dependen atau Y dari nilai beberapa variabel independen atau $\mathrm{X}$.

\section{Uji Koefisien Korelasi}

Uji koefisien korelasi merupakan salah satu analisa yang digunakan untuk menguji korelasi linier antara satu variabel dependen dan beberapa variabel independent (Imron 2019b). Apabila dalam suatu korelasi ganda memiliki beberapa atau lebih dari 2 variabel bebas maka digunakan rumus seperti berikut;

$$
R_{y .123 k}=\sqrt{1-\left\{\left(1-r_{y 1}^{2}\right)\left(1-r_{y 2.1}^{2}\right)\left(1-r_{y 3.12}^{2}\right) \ldots\left(1-r_{y k .123 k-1}^{2}\right)\right\}}
$$

Keterangan :

$$
\begin{aligned}
& \text { Ry.123.k = Kolerasi X1 sampai Xk } \\
& \text { antara dengan } \mathrm{Y} \\
& \text { ry1 }=\text { Kolerasi } \mathrm{X} 1 \text { antara dengan } \mathrm{Y} \\
& \text { ry2.1 }=\text { Kolerasi X1 dan X2 antara } \\
& \text { dengan } \mathrm{Y} \\
& \text { ry3.12= Kolerasi X1 sampai X3 }
\end{aligned}
$$

\section{Uji Koefisien Determinasi}

koefisien determinasi adalah besaran kontribusi variabel bebas terhadap variabel terikat. Cara mendapatkan koefisien determinasi adalah dengan mengkuadratkan koefisien korelasi (Imron 2019b).

Menurut perhitungan koefisien korelasi, maka akan didapatkan hitungan koefisien determinasi yaitu untuk mengetahui berapa besar persentase pengaruh variabel $\mathrm{X}$ yaitu variabel kegunaan, variabel informasi, dan variabel interaksi terhadap variabel $\mathrm{Y}$ yaitu variabel kepuasan pengguna. Berikut ini adalah rumus koefisien determinasi;

$$
K d=r^{2} \times 100 \%
$$

Keterangan :

$\mathrm{Kd}=$ Koefisien Determinasi

$\mathrm{r}^{2}=$ Koefisien korelasi sederhana 
Hasil nilai dari koefisien determinasi akan menunjukkan besaran pengaruh dari beberapa variabel $\mathrm{X}$ terhadap variabel $\mathrm{Y}$ yang dinyatakan dengan persen. untuk mendapatkan nilai koefisien determinasi bisa menggunakan aplikasi SPSS dan dapat dicek melalui tabel model summary pada kolom $r$ square.

\section{Uji t}

Uji $\mathrm{t}$ adalah untuk membuktikan variabel independen secara parsial tidak mempengaruhi variabel dependen(Winanti, Yuniarti, and Nengsih 2020). Untuk menentukan nilai dari hasil uji t dari aplikasi SPSS dapat di cek pada tabel coefficients pada kolom $\mathrm{t}$, untuk membandingkan $\mathrm{t}$ hitung dengan $\mathrm{t}$ tabel maka menggunakan derajat keyakinan dengan level signifikansi $5 \%$ atau 0,05 . Pengambilan keputusan Uji $\mathrm{t}$ didasarkan dengan nilai $\mathrm{t}$ hitung apabila;

a. $\quad \mathrm{H} 0$ diterima dan $\mathrm{Ha}$ ditolak jika nilai $\mathrm{t}$ hitung lebih kecil dari t tabel atau jika nilai sig lebih besar dari 0,05 atau tidak terdapat pengaruh secara parsial antara variabel $\mathrm{X}$ terhadap variabel $\mathrm{Y}$.

b. $\quad \mathrm{H} 0$ ditolak dan $\mathrm{Ha}$ diterima jika nilai $\mathrm{t}$ hitung lebih besar dari t tabel atau jika nilai sig lebih kecil dari 0,05 atau terdapat pengaruh secara parsial antara variabel $\mathrm{X}$

\section{Uji F} terhadap variabel $\mathrm{Y}$.

Uji $F$ adalah uji koefisiensi regresi secara bersama-sama untuk menguji signifikansi pengaruh beberapa variabel $\mathrm{X}$ terhadap variabel $\mathrm{Y}$. Atau bisa dikatakan bahwa uji $\mathrm{F}$ adalah uji yang mengukur seberapa besar perbedaan varians antara variabel independen dan variabel dependen. untuk mencari hasil F dari aplikasi SPSS dapat di cek melalui tabel anova pada kolom F. Ada dua cara yang bisa dilakukan guna mengetahui ada atau tidaknya pengaruh signifikan dalam uji F. Yang pertama adalah dengan cara membandingkan antara $\mathrm{F}$ hitung dan $\mathrm{F}$ tabel, sedangkan yang kedua adalah membandingkan besaran nilai signifikansi atau nilai probabilitas.

Syarat pengambilan keputusan uji $\mathrm{F}$ melalui nilai $\mathrm{F}$ hitung adalah sebagai berikut;

a. jika nilai $F$ hitung lebih besar dari $F$ tabel maka variabel $X$ pada waktu yang bersamaan berpengaruh terhadap variabel Y.

b. Jika nilai $\mathrm{F}$ hitung lebih kecil dari $\mathrm{F}$ tabel maka variabel $X$ pada waktu yang bersamaan tidak mempengaruhi variabel $\mathrm{Y}$. Syarat pengambilan keputusan dalam uji $\mathrm{F}$ melalui nilai signifikansi adalah sebagai berikut;

a. jika nilai signifikansi lebih kecil dari 0,05 maka variabel $X$ secara bersama-sama berpengaruh secara signifikan terhadap variabel $\mathrm{Y}$

b. jika nilai signifikansi lebih besar dari 0,05 maka variabel X secara bersama-sama tidak berpengaruh secara signifikan terhadap variabel $\mathrm{Y}$.

\section{HASIL}

\section{Hasil Uji Validitas}

Uji validitas dilakukan untuk mengetahui dan mengukur apakah sebuah data yang diberikan pada kuesioner bisa dipercaya dan bisa mewakili apa yang sedang diteliti.hasil perhitungan maka diketahui tingkat validitas data penelitian adalah sebagai berikut;

Tabel II

Hasil keseluruhan Variabel dalam Uji Validitas

\begin{tabular}{|c|c|c|c|}
\hline VARIABLE & $\begin{array}{c}\text { NO. } \\
\text { PERTA } \\
\text { NYAAN }\end{array}$ & $\begin{array}{c}\text { r- } \\
\text { HITUNG }\end{array}$ & KET \\
\hline \multirow{5}{*}{$\begin{array}{l}\text { Variabel } \\
\text { Kualitas } \\
\text { Kegunaan } \\
\text { (X1) }\end{array}$} & 1 & $.724 * *$ & Valid \\
\hline & 2 & $.796 * *$ & Valid \\
\hline & 3 & $.765 * *$ & Valid \\
\hline & 4 & $.762 * *$ & Valid \\
\hline & 5 & $.697 * *$ & Valid \\
\hline \multirow{5}{*}{$\begin{array}{c}\text { Variabel } \\
\text { Kualitas } \\
\text { Informasi } \\
\text { (X2) }\end{array}$} & 1 & $.768 * *$ & Valid \\
\hline & 2 & $.808 * *$ & Valid \\
\hline & 3 & $.746 * *$ & Valid \\
\hline & 4 & $.769 * *$ & Valid \\
\hline & 5 & $.829 * *$ & Valid \\
\hline \multirow{5}{*}{$\begin{array}{c}\text { Variabel } \\
\text { Kualitas } \\
\text { Interaksi } \\
\text { (X3) }\end{array}$} & 1 & $.740 * *$ & Valid \\
\hline & 2 & $.759 * *$ & Valid \\
\hline & 3 & $.801 * *$ & Valid \\
\hline & 4 & $.772 * *$ & Valid \\
\hline & 5 & $.744 * *$ & Valid \\
\hline \multirow{5}{*}{$\begin{array}{l}\text { Variabel } \\
\text { Kepuasan } \\
\text { Pengguna } \\
\text { (Y1) }\end{array}$} & 1 & $.738 * *$ & Valid \\
\hline & 2 & $.782 * *$ & Valid \\
\hline & 3 & $.818 * *$ & Valid \\
\hline & 4 & $.756^{* *}$ & Valid \\
\hline & 5 & $.814 * *$ & Valid \\
\hline
\end{tabular}

Berdasarkan data tersebut, dapat diketahui data yang diuji terdiri atas 3 variabel independen atau bebas yang tidak terikat yaitu; variabel kualitas kegunaan, variabel kualitas informasi, dan variabel kualitas 
interaksi, dan satu variabel dependen atau variabel yang terikat yaitu variabel kepuasan pengguna. Diketahui $r$ tabel $(n=400$, maka $n-2=400-2=398$ ) mengacu pada distribusi $r$ tabel dengan tingkat signifikansi 0,05 dari n 400 menunjukkan nilai 0,088 . Pada pengujian validitas di atas menunjukkan seluruh nilai korelasi atau $\mathrm{r}$ hitung dari masingmasing pertanyaan adalah lebih dari nilai $\mathrm{r}$ tabel. Artinya hasil pengujian validitas menunjukkan bahwa semua item pada angket dinyatakan valid dan bisa dijadikan sebagai acuan alat pengumpulan data dalam penelitian.

\section{Hasil Uji Reliabilitas}

Uji reliabilitas dilakukan guna mengukur dan mengetahui sampai sejauh mana dan sebesar apa derajat ketepatan, ketelitian, atau keakuratan yang dapat ditunjukkan instrumen pengukuran. Uji reliabilitas dapat dilakukan menggunakan metode internal consistency. Internal consistency dapat diukur menggunakan koefisien crobach alpha. yang mana syarat-syarat pengambilan keputusan yang digunakan menggunakan metode cronbach alpha adalah;

a. Jika nilai alpha nya lebih besar dari 0,60 maka variabel tersebut dinyatakan reliabel.

b. jika nilai alpha nya lebih kecil dari 0,60 maka variabel tersebut dinyatakan tidak reliabel.

Dari hasil uji reliabilitas yang telah dilakukan menggunakan software SPSS maka diketahui;

\section{Tabel III}

Hasil Uji Reliabilitas Semua Variabel

\begin{tabular}{|l|c|c|c|}
\hline VARIABEL & $\begin{array}{c}\text { NILAI CRONBACH'S } \\
\text { ALPHA }\end{array}$ & KRITERIA & KETERANGAN \\
\hline Kualitas Kegunaan & 0.802 & 0.60 & Realible \\
\hline Kualitas Informasi & 0.841 & 0.60 & Realible \\
\hline Kualitas Interaksi & 0.819 & 0.60 & Realible \\
\hline Kepuasan Pengguna & 0.834 & 0.60 & Realible \\
\hline
\end{tabular}

Dari hasil uji reliabilitas variabel data penelitian memiliki 400 orang responden dan dapat diperoleh nilai realibility statistik cronbach's alpha yang masing-masing variabelnya menunjukkan nilai di atas 0,60. Maka dapat dinyatakan data hasil penelitian maka di dapat di simpulkan hasil uji reliabilitas ini adalah reliabel dan data yang didapatkan memenuhi persyaratan kualitas.

\section{Uji Asumsi Klasik}

Untuk melakukan analisa dengan menggunakan metode regresi linear berganda maka sebelumnya dilakukan uji persyaratan analisis yaitu uji asumsi klasik. Yang dilakukan dalam uji asumsi klasik adalah adanya beberapa pengujian yaitu meliputi uji normalitas, uji multikolinearitas, uji heteroskedastisitas, uji linieritas, dan uji auto korelasi. Pengujian nya adalah masing-masing sebagai berikut:

\section{a. Uji Normalitas}

Uji normalitas dilakukan untuk mengetahui apakah data yang didapatkan berdistribusi dengan baik atau tidak atau data-data itu normal atau tidak dalam pendistribusiannya. Pada pengujian uji normalitas pada penelitian ini menggunakan metode kolmogorov smirnov dengan menggunakan bantuan perhitungan dari software SPSS dengan hasil seperti berikut;

Tabel IV

One-Sample Kolmogorov-Smirnov Test

\begin{tabular}{|c|c|c|}
\hline & & Unstandardized Residual \\
\hline \multicolumn{2}{|l|}{$\mathrm{N}$} & 400 \\
\hline \multirow{2}{*}{$\begin{array}{c}\text { Normal } \\
\text { Parameters }\end{array}$} & Mean & .0000000 \\
\hline & $\begin{array}{c}\text { Std. } \\
\text { Deviatio } \\
\mathrm{n}\end{array}$ & 1.43429497 \\
\hline \multirow{3}{*}{$\begin{array}{l}\text { Most Extreme } \\
\text { Differences }\end{array}$} & Absolute & .139 \\
\hline & Positive & .099 \\
\hline & Negative & -.139 \\
\hline \multicolumn{2}{|c|}{ Test Statistic } & .139 \\
\hline \multicolumn{2}{|c|}{ Asymp. Sig. (2-tailed) } & $.000^{\mathrm{c}}$ \\
\hline
\end{tabular}

a. Test distribution is Normal.

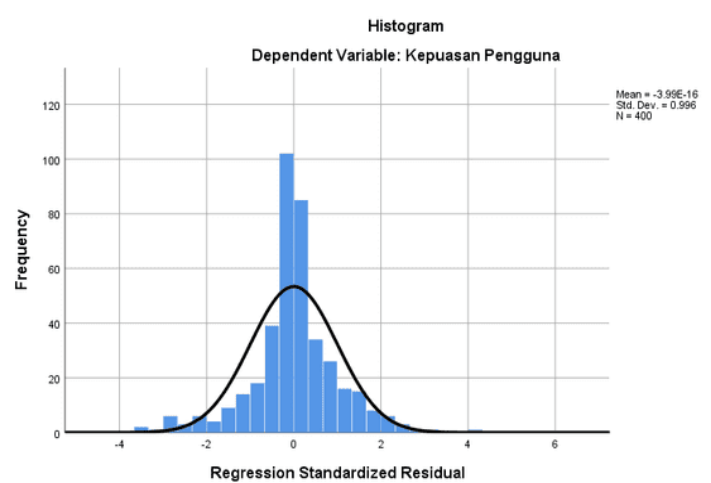




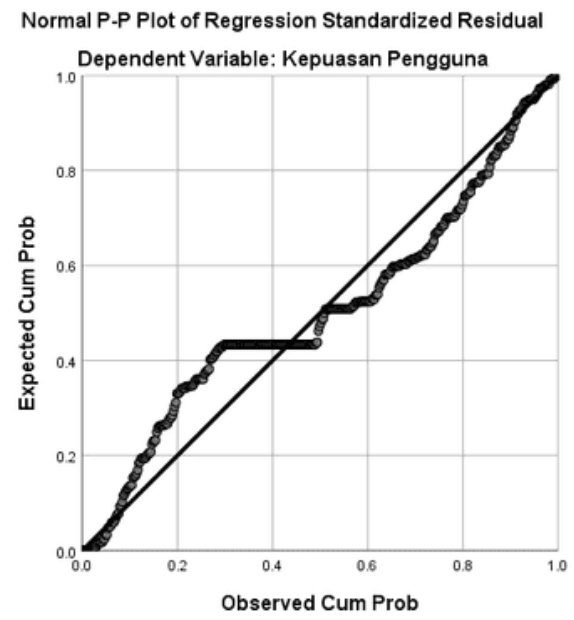

Pengambilan keputusan yang dilakukan pada uji normalitas kali ini adalah nilai signifikansi apakah lebih besar dari 0,05 maka dikatakan tidak berdistribusi dengan normal. Dan dari gambar P-P Plot dimana gambanya tidak mengikuti garis yang tepat dan dari pengujian yang telah dilakukan yang telah disajikan di tabel diatas yang menunjukkan bahwa nilai signifikansi lebih kecil dari 0, 05 dan data ini membuktikan bahwa variabel berdistribusi secara tidak normal.

Karena telah dibuktikan bahwa data tidak berdistribusi secara normal, maka yang perlu dilakukan ada menormalisasi data karena data yang normal adalah syarat mutlak untuk melakukan uji uji selanjutnya yaitu uji parsial dan uji uji lainnya yang membutuhkan kenormalan data.

Maka dari itu kita harus mencari tahu kenapa data tidak normal dan harus mengklasifikasikannya dan mencari cara yang tepat untuk mengatasi hal tersebut, salah satu cara yang dapat dilakukan adalah mentransformasi data namun sebelumnya kita harus tahu pola apa yang terjadi di data tersebut sehingga tidak normal, selamanya kita akan melakukan tindakan yang tepat untuk menormalkan data tersebut.

jadi gambar histogram yang dapat kita lihat di atas adalah grafik menunjukkan kecondongan ke arah kanan. Grafik tersebut menggambarkan kurve kita condong ke kanan. Beberapa kemungkinan grafik yang akan muncul adalah sebagai berikut.

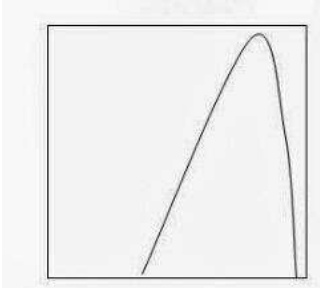

Subtansial Negative Skewness

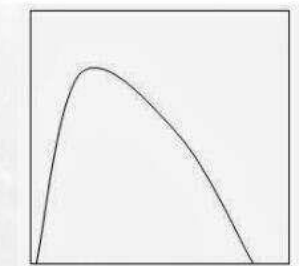

Moderate Positive Skewness

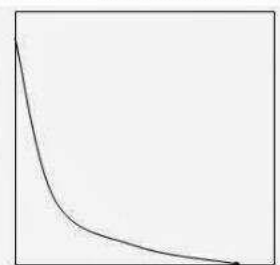

Severe Positive Skewness

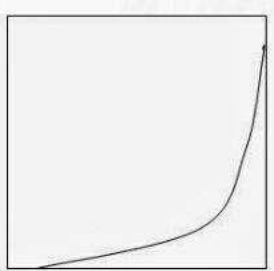

Severe Negative Skewness

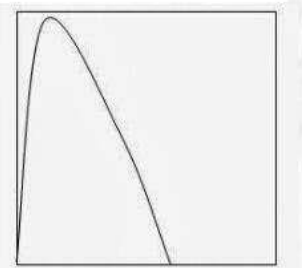

Subtantial Positive Skewness

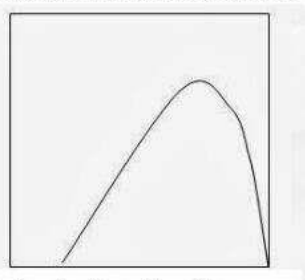

Moderate Negative Skewness
Tabel V

Transformasi Data

\begin{tabular}{|l|l|}
\hline Bentuk Grafik Histogram & $\begin{array}{l}\text { Bentuk } \\
\text { Transformas } \\
\text { i Data }\end{array}$ \\
\hline Moderate positive skewness & SQRT(x) \\
\hline Substansial positive skewness & LG10(x) \\
\hline Severe positive skewness & $1 / x$ \\
\hline Moderate negative skewness & SQRT(k-x) \\
\hline Substansial negative skewness & LG10(k-x) \\
\hline Severe negative skewness & $1 /(k-x)$ \\
\hline
\end{tabular}

Jika kembali melihat ke data dan melihat grafik histogram, maka bentuk grafik yang ada adalah subtansial negative skewness, sehingga transformasi data yang kita pakai adalah SQRT(k-x) lalu akan ditemukan hasil berupa:

Tabel VI

One-Sample Kolmogorov-Smirnov

Test

Unstan

dardize

d

Residu

al

\begin{tabular}{|llr|}
\hline $\mathrm{N}$ & & 400 \\
\hline Normal & Mean & .00000 \\
Param & & 00 \\
\cline { 2 - 3 } eters $^{\mathrm{a}, \mathrm{b}}$ & Std. Deviation & 21.557 \\
& & 28042 \\
\hline & Absolute & .029 \\
\hline
\end{tabular}




\begin{tabular}{|c|c|c|c|}
\hline \multirow{2}{*}{$\begin{array}{l}\text { Most } \\
\text { Extrem } \\
\text { e } \\
\text { Differe } \\
\text { nces }\end{array}$} & \multicolumn{2}{|c|}{ Positive } & .029 \\
\hline & \multicolumn{2}{|c|}{ Negative } & -.013 \\
\hline \multicolumn{3}{|c|}{ Test Statistic } & .029 \\
\hline \multicolumn{3}{|c|}{ Asymp. Sig. (2-tailed) } & $200^{c, d}$ \\
\hline \multirow{3}{*}{$\begin{array}{l}\text { Monte } \\
\text { Carlo } \\
\text { Sig. (2- } \\
\text { tailed) }\end{array}$} & \multicolumn{2}{|l|}{ Sig. } & $.888^{\mathrm{e}}$ \\
\hline & \multirow{2}{*}{$\begin{array}{l}99 \% \\
\text { Conf } \\
\text { iden } \\
\text { ce } \\
\text { Inter } \\
\text { val }\end{array}$} & $\begin{array}{l}\text { Lower } \\
\text { Bound }\end{array}$ & .880 \\
\hline & & $\begin{array}{l}\text { Upper } \\
\text { Bound }\end{array}$ & .896 \\
\hline
\end{tabular}

a. Test distribution is Normal.

b. Calculated from data.

c. Lilliefors Significance Correction.

$\mathrm{d}$. This is a lower bound of the true significance.

e. Based on 10000 sampled tables with starting seed 2000000 .

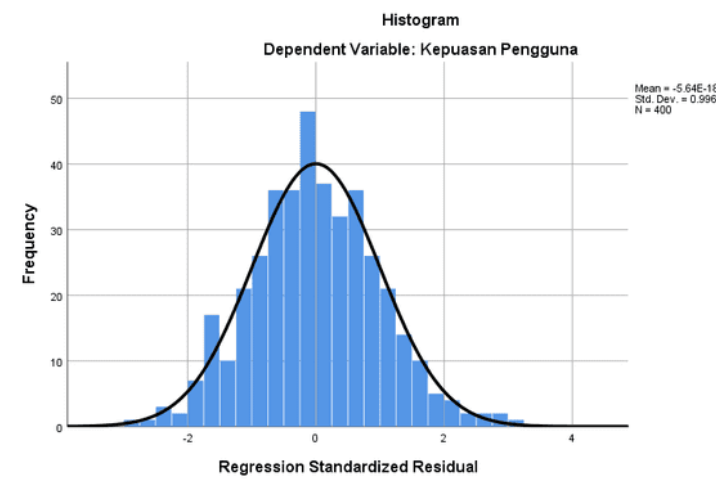

Normal P.P Plot of Regression Standardized Residual

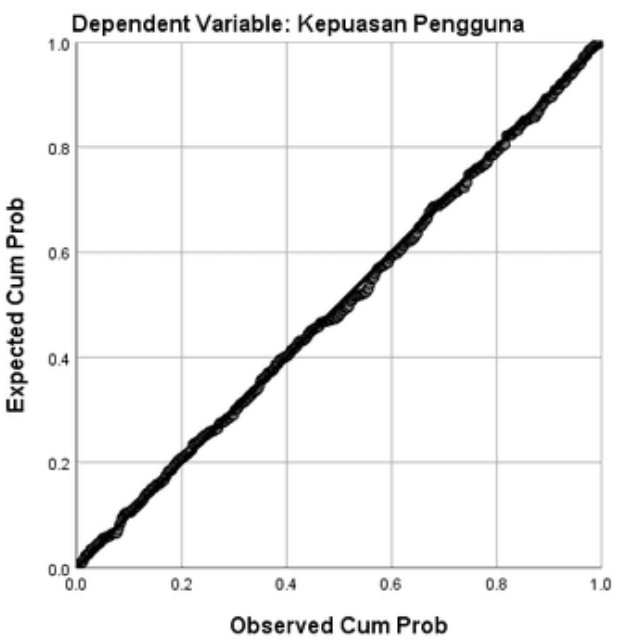

Pengambilan keputusan yang dilakukan pada uji normalitas kali ini adalah jika nilai signifikansi apakah lebih besar dari 0,05. Jika Iya maka data tersebut tandanya berdistribusi normal karena Asymp. Sig. (2-tailed) memiliki angka signifikansi 0,200 dan Monte Carlo Sig. (2-tailed) memiliki signifikasi 0,888 yang lebih besar dari 0,05 sehingga dapat dikatakan bahwa sekarang data berdistribusi dengan normal, selanjutnya untuk melakukan pemastian pembuktian dapat dilihat lagi dari gambar histogram yang sudah sempurna, dan dibuktikan lagi dari ganbar P-P Plot dimana gambanya mengikuti garis yang tepat, tidak berantakan. Dari pengujian yang telah dilakukan setelan data di transform yang telah disajikan di tabel diatas maka dapat dipastikan bahwa data menunjukkan nilai signifikansi lebih besar dari 0, 05 dan data ini membuktikan bahwasanya variabelvariabelnya berdistribusi secara normal.

\section{b. Uji Multikolinieritas}

Uji multikolinearitas bertujuan untuk membuktikan ada tidaknya korelasi yang signifikan mendekati sempurna antar variabel independen. Kalau sesama variabel independen terdapat orasi yakni signifikan maka dikatakan model regresi linear tersebut terdapat gejala multikolinearitas.

$$
\text { Tabel VII }
$$

Hasil Uji Multikolinieritas

Coefficients $^{\mathrm{a}}$

\begin{tabular}{|c|c|c|c|c|c|c|c|}
\hline \multirow[b]{2}{*}{ Model } & $\begin{array}{r}\text { Unst } \\
\text { Co }\end{array}$ & $\begin{array}{l}\text { ardized } \\
\text { cients }\end{array}$ & \multirow[t]{2}{*}{$\begin{array}{c}\text { Standardize } \\
\mathrm{d} \\
\text { Coefficient } \\
\mathrm{s} \\
\text { Beta }\end{array}$} & \multirow[b]{2}{*}{$\mathrm{t}$} & \multirow[b]{2}{*}{ Sig. } & \multicolumn{2}{|c|}{$\begin{array}{c}\text { Collinearity } \\
\text { Statistic }\end{array}$} \\
\hline & B & Std. Error & & & & Tolerance & VIF \\
\hline $\begin{array}{ll}1 & \text { (Constant) }\end{array}$ & 1.332 & .666 & & 2.000 & .046 & & \\
\hline $\begin{array}{c}\text { Kualitas } \\
\text { Kegunaan }\end{array}$ & .329 & .040 & .332 & 8.212 & .000 & .504 & 1.986 \\
\hline $\begin{array}{l}\text { Kualitas } \\
\text { Informasi }\end{array}$ & .346 & .048 & .322 & 7.180 & .000 & .409 & 2.444 \\
\hline $\begin{array}{l}\text { Kualitas } \\
\text { Interaksi }\end{array}$ & .270 & .045 & .270 & 6.042 & .000 & .413 & 2.423 \\
\hline
\end{tabular}

a. Dependent Variable: Kepuasan Pengguna

Untuk membuktikan ada tidaknya multikolinearitas pada data yang telah dikumpulkan maka kita mengujinya dengan software SPSS dengan mengecek toleransi dan VIFnya yang tersaji dalam hasil berikut;

Hal diatas membuktikan bahwa nilai keseluruhan toleransi adalah lebih besar dari 0,01 dan nilai keseluruhan VIF adalah kurang dari 10. Maka dari itu membuktikan bahwa tidak terjadi gejala multikolinearitas.

\section{c. Uji Heterokedastisitas}

Berikut adalah gambar scatterplots antara standardized residual dan standardized predictive value dan pada gambar tersebut dapat dilihat bahwa tidak membentuk suatu pola tertentu, tidak membentuk gelombang-gelombang tertentu dan tidak mengumpul di suatu titik, juga tidak melebar dan menyempit ataupun sebaliknya. Maka dapat dianggap residualnya memiliki varian yang konstan dan dapat disimpulkan bahwa tidak terjadi 
heteroskedastisitas.

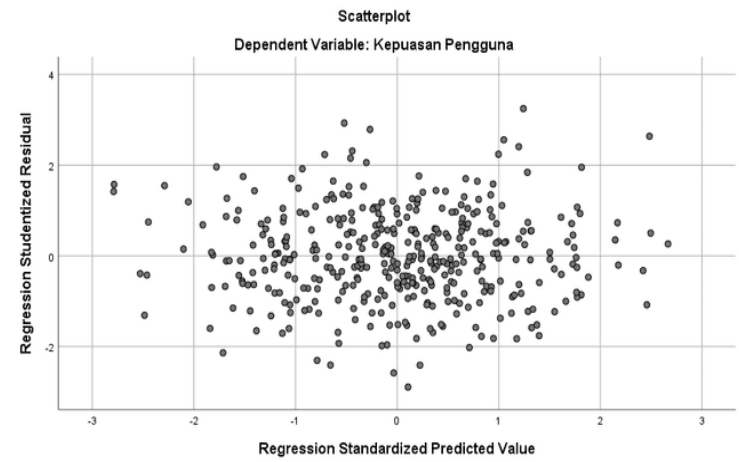

\section{d. Uji Linieritas}

Melakukan uji linearitas adalah untuk mengetahui apakah dua variabel mempunyai sebuah hubungan yang linier secara signifikan atau tidak. Dengan menggunakan software SPSS maka hasilnya dapat dilihat pada tabel berikut;

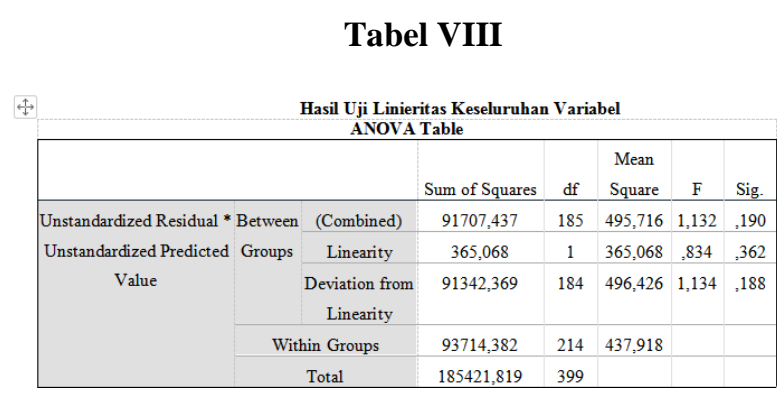

Dari pembuktian perhitungan Unstandardized Residual dan Unstandardized Predicted Value yang mewakili nilai variabel independen dengan variabel dependen secara keseluruhan yang telah dilakukan di atas dan mendapatkan nilai signifikansi pada Deviation from linierity sebesar 0,188 dan 0,362 pada linierity yang mana keduanya memiliki angka lebih besar daripada 0,05 , maka dapat disimpulkan bahwa semua variabel $\mathrm{X}$ yaitu variabel kualitas kegunaan, kualitas informasi, dan kualitas interaksi bersifat linier kepada variabel $\mathrm{Y}$ yaitu variabel kepuasan pengguna.

\section{Koefisien Korelasi dan Koefisien Determinasi}

Kegunaan dari uji koefisien korelasi adalah untuk mengetahui seberapa besar tingkat keeratan hubungan yang dimiliki antar variabel dalam sebuah penelitian. Uji koefisien korelasi dapat dicek pada tabel yang tersaji berikut;

Tabel IX

Hasil Uji Koefisien Korelasi dan Determinasi Model Summary ${ }^{\mathrm{b}}$

\begin{tabular}{|lllll|}
\hline & & & \multicolumn{3}{l|}{ Adjusted Std. Error of the } \\
Model R & R Square & R Square Estimate \\
\hline 1 & $.820^{\mathrm{a}}$ & .673 & .671 & 1.43972 \\
\hline
\end{tabular}

a. Predictors: (Constant), Kualitas Interaksi, Kualitas

Kegunaan, Kualitas Informasi

b. Dependent Variable: Kepuasan Pengguna
Output model summary menjelaskan besarnya nilai $\mathrm{r}$ atau nilai korelasi yaitu sebesar 0,820 dan menjelaskan besaran persentase pengaruh variabel bebas independen terhadap variabel dependen sebagai koefisien determinasi yang merupakan hasil dari pengkuadratan r. Output tersebut didapatkan koefisien determinasi yang dilambangkan dengan $\mathrm{R}$ kuadrat dengan nilai sekitar 0,673 yang memiliki pengertian bahwasanya pengaruh variabel independen terhadap variabel dependen adalah sekitar $67,3 \%$ dan sisanya didapatkan dari variabel-variabel lain yang tidak terikutsertakan di dalam penelitian.

\section{Hasil Uji t}

\section{Tabel X}

Hasil Uji t

\begin{tabular}{|c|c|c|c|c|c|c|}
\hline & \multirow[b]{2}{*}{ Model } & \multicolumn{2}{|c|}{$\begin{array}{l}\text { Unstandardized } \\
\text { Coefficients }\end{array}$} & \multirow{2}{*}{$\begin{array}{c}\text { Standardized } \\
\text { Coefficients } \\
\text { Beta }\end{array}$} & \multirow[b]{2}{*}{$\mathrm{t}$} & \multirow[b]{2}{*}{ Sig. } \\
\hline & & B & Std. Error & & & \\
\hline \multirow[t]{4}{*}{1} & (Constant) & 1.332 & .666 & & 2.000 & .046 \\
\hline & Kualitas Kegunaan & .329 & .040 & .332 & 8.212 & .000 \\
\hline & Kualitas Informasi & .346 & .048 & .322 & 7.180 & .000 \\
\hline & Kualitas Interaksi & .270 & .045 & 270 & 6.042 & .000 \\
\hline
\end{tabular}

Menurut tabel diatas ditunjukkan bahwa variabel X1 dengan label kualitas kegunaan memiliki nilai $\mathrm{T}$ hitung sebesar 8, 212. Setelah membuktikan variabel X1 maka setelahnya menghitung dan membuktikan variabel $\mathrm{x}$ dua yaitu kualitas informasi. Menurut tabel diatas ditunjukkan bahwa variabel X2 dengan label kualitas informasi memiliki nilai T hitung sebesar 7,180. Yang terakhir adalah pembuktian variabel X3 atau kualitas interaksi. Menurut tabel diatas ditunjukkan bahwa variabel X3 dengan label kualitas Interaksi memiliki nilai $\mathrm{T}$ hitung sebesar 6,042 .

\section{Hasil Uji F}

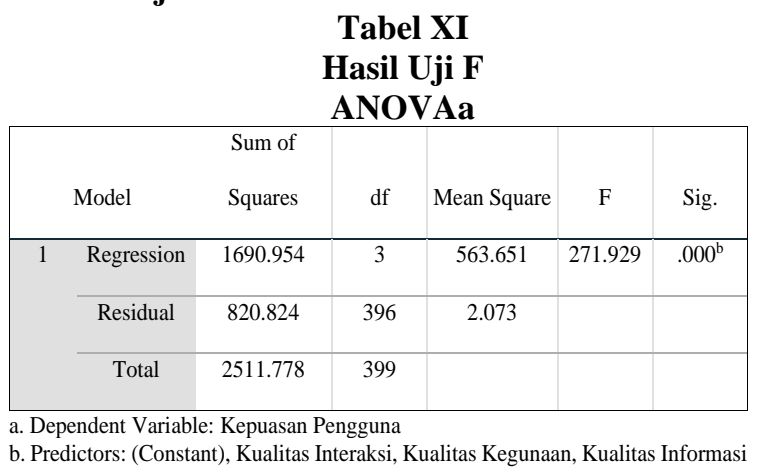

Berdasarkan hasil perhitungan $\mathrm{F}$ hitung diperoleh nilai F sebesar 271.929 dengan signifikansi sebesar 0,000 yang menunjukan bahwa signifikansinya lebih kecil dari 0,05 . Nilai $F$ tabel diperoleh dengan mencari $\mathrm{N} 1$ dan $\mathrm{N} 2$, dengan nilai $\mathrm{n}$ adalah sebanyak jumlah responden (400), $\mathrm{k}$ adalah 
jumlah semua variabel (4). Dari nilai tersebut, diperoleh nilai $\mathrm{N} 1=4-1=3 \quad(\mathrm{df}=\mathrm{N} 1=\mathrm{k}-1) \quad$ dan $\mathrm{N} 2=400-4=396(\mathrm{df}=\mathrm{N} 2=\mathrm{n}-\mathrm{k})$ dan bisa mengeceknya ke tabel $\mathrm{F}$, besarannya adalah 2,627. Hasil analisis menunjukkan bahwa nilai $\mathrm{F}$ hitung $>\mathrm{F}$ tabel $(271.929>2,67)$. Hal ini berarti kualitas kegunaan, kualitas informasi, dan kualitas interaksi secara bersama-sama(secara simultan) berpengaruh terhadap kepuasan pengguna.

\section{KESIMPULAN}

a. Berisi Merujuk pada nilai korelasi dan koefisien sebesar 0,820 yang menandakan bahwa ada hubungan yang sangat kuat antara variabel $\mathrm{Y}$ yaitu kepuasan pengguna dengan variabel $\mathrm{X}$, yaitu; kualitas kegunaan, kualitas informasi, dan kualitas interaksi.

b. Berdasarkan hasil analisis regresi linier berganda diperoleh persamaan yaitu $\mathrm{Y}=$ $4,994+0,245 \mathrm{X} 1+0,079 \mathrm{X} 2+0,432 \mathrm{X} 3$

c. nilai korelasi yaitu sebesar 0,820 dan menjelaskan besaran persentase pengaruh variabel bebas independen terhadap variabel dependen sebagai koefisien determinasi, $\mathrm{R}$ kuadrat dengan nilai sekitar 0,673 yang memiliki pengertian bahwasanya pengaruh variabel independen terhadap variabel dependen adalah sekitar $67,3 \%$ dan sisanya didapatkan dari variabel-variabel lain yang tidak terikutsertakan di dalam penelitian.

Hasil analisis menunjukkan bahwa nilai $\mathrm{F}$ hitung > F tabel (271.929 > 2,67 ). Hal ini berarti kualitas kegunaan, kualitas informasi, dan kualitas interaksi secara bersama-sama (secara simultan) berpengaruh terhadap kepuasan pengguna.

\section{PUSTAKA}

Darwi, Apris Robi, and Efrizon. 2019. “Analisis Kepuasan Pengguna E-Learning Sebagai Pendukung Aktivitas Pembelajaran Menggunakan Metode Eucs.” Jurnal Vokasional Reknik Elektronika Dan Informatika (Voteknika) 7 (1): 25-31.

Imron, Imron. 2019a. “Analisa Pengaruh Kualitas Produk Terhadap Kepuasan Konsumen Menggunakan Metode Kuantitatif Pada CV. Meubele Berkah Tangerang." Indonesian Journal on Software Engineering (IJSE) 5 (1): 19-28. https://doi.org/10.31294/ijse.v5i1.5861. 2019b. "Analisis Kualitas Website Terhadap Kepuasan Pengguna Dengan Metode Webqual 4.0 Studi Kasus: Rumah Wisata Keramik F.Widayanto Depok.” Jurnal Ilmiah Informatika Global 10 (1): 32-37. https://doi.org/10.36982/jig.v10i1.733.

kemendikbud. 2017. “Panduan E-Rapor SMP.” In . Jakarta. http://ditsmp.kemdikbud.go.id/erapor/.

Kharisma, Mala, and Sita Anggraeni. 2018. "Pengaruh Kualitas Layanan Bjb Net Terhadap Kepuasan Nasabah Bank Bjb Rasuna Said Menggunakan Metode Webqual 4.0." Jurnal TECHNO Nusa Mandiri 15 (1): 13-18. http://ejournal.nusamandiri.ac.id/ejurnal/inde x.php/techno/article/viewFile/808/pdf.

Wildaningsih, Wili, and Aneu Yulianeu. 2018.

"Sistem Informasi Pengolahan Data Anggota Unit Keagiatan Mahasiswa (UKM) Zaradika STMIK DCI Tasikmalaya.” Jumantaka 2 (1): 181-90. http://jurnal.stmik-

dci.ac.id/index.php/jumantaka/article/view/36 4.

Winanti, Wiwin, Puji Yuniarti, and Siska Rahmadia Nengsih. 2020. "Pengaruh Budaya Organisasi Terhadap Kinerja Pegawai Bagian Sdm Dan Umum PT PLN (Persero) Jakarta Selatan." Jurnal Ilmiah Manajemen 8 (3). 